\title{
Effects of an Antioxidant Protective Topical Formulation on Eye Exposed to Ultraviolet-Irradiation: a Study in Rabbit Animal Model
}

\author{
F. VIZZARRI ${ }^{1}$, M. PALAZZO ${ }^{1}$, S. BARTOLLINO ${ }^{2}$, D. CASAMASSIMA ${ }^{1}$, B. PAROLINI ${ }^{3}$, \\ P. TROIANO ${ }^{4}$, C. CARUSO ${ }^{5}$, C. COSTAGLIOLA ${ }^{2}$
}

${ }^{1}$ Department of Agricultural, Environmental and Food Sciences, University of Molise, Campobasso, Italy, ${ }^{2}$ Department of Medicine and Health Science "V. Tiberio", University of Molise, Campobasso, Italy, ${ }^{3}$ Department of Ophthalmology, Sant'Anna Institute, Brescia, Italy, ${ }^{4}$ Department of Ophthalmology, Fatebenefratelli Sacred Family Hospital, Erba, Italy, ${ }^{5}$ Corneal Transplant Center, Pellegrini Hospital, Naples, Italy

Received September 10, 2017

Accepted January 22, 2018

On-line March 12, 2018

\section{Summary}

Ultraviolet-radiation exerts a well-known role in the development of various ocular diseases and may contribute to the progress of age-related macular degeneration. Therefore, the use of compounds able to protect the eyes from UV-induced cellular damage is challenging. The aim of this study has been to test the protective effects of an antioxidant topical formulation against UV-induced damage in rabbit eyes. Twelve male rabbits were used. Animals were divided into 4 groups of 3 animals each. Control group (CG) did not receive any irradiation and/or eye drop. The other three experimental groups were treated as follows: the first group received only UVR irradiation for $30 \mathrm{~min}$, without eye drop supplementation (Irradiation group, IG), the second (G30) and the third (G60) groups received UV irradiation for $30^{\prime}$ and $60^{\prime}$, respectively, and eye drop supplementation (riboflavin, d-a-tocopheryl polyethylene glycol, proline, glycine, lysine and leucine solution) every 15 min for three hours. In the IG group a significant increase of oxidized glutathione (GSSG) and hydrogen peroxide $\left(\mathrm{H}_{2} \mathrm{O}_{2}\right)$ was recorded in the aqueous humor, whereas ascorbic acid levels were significantly lower when compared to control eyes. In the groups exposed to UVR rays for $30 \mathrm{~min}$, and treated with the topical antioxidant formulation, the GSSG, $\mathrm{H}_{2} \mathrm{O}_{2}$ and ascorbic acid levels were similar to those recorded in controls, whereas in the G60 group the three markers significantly differ from control group. In the lens, a significant decrease of alpha tocopherol and total antioxidant capacity (TAC) was recorded in IG-animals as compared to control group, whereas malondialdehyde (MDA) levels were significantly higher in UV-induced eye than in control eyes. In the G30 groups the alpha tocopherol, MDA and TAC levels do not significantly differ from those recorded in controls, whereas in the $\mathrm{G} 60$ group these three markers significantly differ from control group. Present findings demonstrate that topical treatment with the antioxidant formulation used herein protects ocular structures from oxidative stress induced by UV exposure in in vivo animal model.

\section{Key words}

UV exposure • Oxidative stress • Antioxidant eye-drops

\section{Corresponding author}

F. Vizzarri, Department of Agricultural, Environmental and Food Sciences, University of Molise, Campobasso, Italy. E-mail: francesco.vizzarri@unimol.it

\section{Introduction}

Ultraviolet radiation (UVR) is commonly divided into three components: $i$ ) UV-A (315 to $400 \mathrm{~nm}$ ) radiation, that causes tanning but is also thought to contribute to aging of the skin and skin cancer; ii) UV-B ( 280 to $315 \mathrm{~nm}$ ) represents the short wavelength radiation that can cause sunburn and predispose to skin cancer; iii) UV-C (100 to $280 \mathrm{~nm}$ ), which is completely absorbed by the ozone layer (Beissert and Loser 2008). Eyes and skin are the organs most highly exposed to UVR and its 
potentially damaging effects; in fact, both UV-A and UV-B radiation may cause injury. Although UV-A has lower energy, it penetrates much deeper into the eye; UV-B is more damaging due to its higher energy. In general, shorter wavelengths of UVR and visible light penetrate tissues less than longer wavelengths. Sunlight contains much more UV-A than UV-B. Neither UV-B nor UV-A has been shown to be beneficial to the eye. Cornea, lens, and retina exhibit acute and chronic inflammatory changes when exposed to UVR (Aly and Ali 2014).

The UVR reaching ocular surface is reflected, absorbed, and transmitted (Kochevar 1989). The amount of reflected light is practically negligible and it is completely absorbed by the tear film (Daush et al. 1991). The interaction between corneal tissue and UV light, has been studied to verify the occurrence of DNA damage. In fact, it is well-known that DNA exhibits absorption maxima at $190 \mathrm{~nm}$ and $260 \mathrm{~nm}$. In mammalian cells, DNA damage and mutation due to these radiations are less severe than those predicted from DNA absorption. Probably, it is due to the shielding of the cellular DNA by the cytoplasm and cell membranes that are optically dense at the same wavelength range (Costagliola et al. 1994). The spectrum between 250 and $350 \mathrm{~nm}$ penetrates deeper into the eye where it can generate phototoxic and cataractogenic effects (Ediger 1991). Several studies have reported that the UV exposure has been consistently associated with the risk for cataract (Sui et al. 2013, Roberts 2011, McCarty and Taylor 2002). Wu et al. (2006) found that UV irradiation has a dose-dependent effect on DNA single strand breaks of lens epithelial cells. As reported by Čejková et al. (2004), ocular tissues and fluids contain both low molecular weight antioxidants (such as ascorbic acid, glutathione and alpha-tocopherol) and high molecular weight antioxidants (such as catalase, CAT; superoxide dismutase, SOD; glutathione peroxidase, GSH-Px; and reductase, GSH-Rx) to protect ocular structures from oxidative damage. In fact, under physiological conditions, these factors protect the cornea against oxidative stress (Čejková et al. 2000). UV exposure induces an increase in cellular reactive oxygen species (ROS) production (Said et al. 2007), which is responsible for the direct cleavage of stromal glycosaminoglycans and alteration of their physiological properties in cornea (Carubelli et al. 1990). In the lens UV radiation causes the decreased of SOD, GSH-Px, and CAT activity, and may be responsible for the decrease of cell density in the lens epithelium (Johar et al. 2003). Most of the UV-B rays are absorbed by the cornea and lens to protect the retina; however, when the eye is exposed to UV-B, also the retina is damaged. Lens and retina are the ocular tissues where UV radiation is able to induce the most important pathological conditions, such as cataract formation and retinal degeneration (Midelfart 2003, Glickman 2011).

However, also in the development of other ocular diseases like cancer of the skin around the eye, photokeratitis, corneal degenerative changes and pterygium the role exerted by UVR is well-known. Therefore, the use of compounds able to protect the eyes from UV-induced cellular damage is challenging. The present study was performed to evaluate the protective effect of topical antioxidant formulation on UV-induced damage in rabbit eyes.

\section{Methods}

\section{Animals}

Twelve male rabbits (New Zealand White, 2.5-3.0 kg) were used. Animals were divided into 4 groups of 3 animals each. Control group (CG) did not receive any irradiation and/or eye drop. The other three experimental groups were treated as follows: the first group received only UVR irradiation for $30 \mathrm{~min}$, without eye drop (Irradiation group, IG), the second (G30) and the third (G60) groups received UV radiation for $30 \mathrm{~min}$ and $60 \mathrm{~min}$, respectively, and eye drop every $15 \mathrm{~min}$ for three hours. The study has been conformed to the ARVO Statement for Use of Animals in Ophthalmic and Vision Research, and in accordance with the guidelines of the European Economic Community for animal care and welfare (EEC Law No. 86/609). Animals were killed by injection of an overdose of sodium pentobarbital, preceded by anesthesia with Xylazine and Ketamine $\mathrm{HCl}$.

\section{UVR radiation}

Prior to UVR radiation, rabbits were sedated with an intramuscular injection of Xylazine $(20 \mathrm{mg} / \mathrm{kg})$ and Ketamine $\mathrm{HCl}(5 \mathrm{mg} / \mathrm{kg})$. During radiation, the rabbits were confined in a cage protecting most of the animal, except the head, from the UVR light. Eyes of anesthetized rabbits were exposed to UVR radiation using a Desaga MinUvis Hg (Sarstedt AG \& Co., Nümbrecht, Germany) with the following properties: one low-pressure lamp at $254 \mathrm{~nm} 1.0 \mathrm{~mW} / \mathrm{cm}^{2}$ and one low-pressure lamp at $366 \mathrm{~nm}, 1.2 \mathrm{~mW} / \mathrm{cm}^{2}$ ). A distance of $7 \mathrm{~cm}$ from the cornea was chosen, according to the 
procedure described by Giblin et al. (2012). The rabbits of IG, G30 and G60 were undergone to the radiation $\left(100 \mathrm{~mW} / \mathrm{cm}^{2}\right)$ for 30 and $60 \mathrm{~min}$. The irradiance on the cornea was $100 \mathrm{~mW} / \mathrm{cm}^{2}$, with a total fluence of $180 \mathrm{~J} / \mathrm{cm}^{2}$ and $360 \mathrm{~J} / \mathrm{cm}^{2}$, respectively. Immediately after the UVR exposure, rabbit eyes of G30 and G60 groups were topically treated every $15 \mathrm{~min}$ for $3 \mathrm{~h}$ with 1 drop (approximately $50 \mu 1$ ) of the antioxidant formulation.

\section{Ophthalmic preparation}

For the procedure, rabbit eyes were topically treated every $15 \mathrm{~min}$ for $3 \mathrm{~h}$ with 1 drop (approximately $50 \mu 1$ ) of ophthalmic antioxidant formulation, provided by Iros sc S.r.l. (Italy), patent no. EP 2459186, USP 9192594), which consisted of a riboflavin, d- $\alpha$-tocopheryl polyethylene glycol (TPGS vitamin E), proline, glycine, lysine and leucine solution, $\mathrm{pH}$ 7.2.

\section{Antioxidant measurements}

At the end of experiments animals were sacrificed with an overdose of sodium pentobarbital $(100 \mathrm{mg} / \mathrm{kg}$ e.v.), and the eyes immediately removed. Antioxidant measurements were carried out on aqueous humor and lenses. Aqueous humor was withdrawn from the eyes with a sterile tuberculin syringe. Samples from two eyes of each rabbit were pooled together, as well as lenses.

Aqueous humor oxidized glutathione (GSSG) content was carried out spectrophotometrically with NADPH2 and glutathione reductase (Bergmeyer 1963). The reaction went to completion and the amount of GSSG was calculated from the change in extinction at $340 \mathrm{~nm}$. NADPH2 was prepared by the method reported in Pirie (1965). The concentrations of ascorbic acid (AA) and hydrogen peroxide $\left(\mathrm{H}_{2} \mathrm{O}_{2}\right)$ in aqueous humor were measured simultaneously on the same sample by the spectrophotometric method described by Pirie (1965). The decrease in the absorbance at $610 \mathrm{~nm}$ resulting from the addition of $0.05 \mathrm{ml}$ of aqueous humor to $3 \mathrm{ml}$ of $50 \mathrm{mM}$ phosphate buffer, $\mathrm{pH} 6.6$, containing $0.04 \mathrm{mM}$ 2,6-dichlorophenol-indophenol was first recorded. Five microliters of $5 \mathrm{mg} / \mathrm{ml}$ horseradish peroxidase solution (Sigma) was then added and the increase in absorbance at the same wavelength due to reoxidation of the dye by $\mathrm{H}_{2} \mathrm{O}_{2}$ was measured. The initial decrease in absorbance is proportional to the concentration of the ascorbic acid, while the increase in absorbance in the second step is equivalent to the concentration of $\mathrm{H}_{2} \mathrm{O}_{2}$. Concentrations of ascorbic acid and $\mathrm{H}_{2} \mathrm{O}_{2}$ in the aqueous humor were calculated using a molecular extinction coefficient of 21,000 (at $610 \mathrm{~nm}$ ) for the oxidized dye. All measurements made in triplicate and averaged.

Lenses were carefully removed under microscopy and immediately washed with normal physiological saline and then processed. Each sample was homogenized for $60 \mathrm{~s}$ in equal volume of $50 \mathrm{mM}$ phosphate buffer $(\mathrm{pH} 7.2)$ and centrifuged at $12,000 \times \mathrm{g}$ for $15 \mathrm{~min}$ at $4{ }^{\circ} \mathrm{C}$. The supernatant obtained was used for analysis. Malondialdehyde was determined according to the method of Ohkawa et al. (1979). Samples were homogenized in a solution of $1.15 \%$ of $\mathrm{KCl}$, to form $10 \%$ homogenates, and $1,500 \mathrm{rpm}$, for $1 \mathrm{~min}$ on ice. Prepared solutions were added to test tubes, vortexed and the tubes were kept in boiling water for $1 \mathrm{~h}$. The tap water-cooled tubes were centrifuged at 3,000 rpm for $10 \mathrm{~min}$. The absorbance of the supernatant was read at $532 \mathrm{~nm}$, and the results were expressed as $\mu \mathrm{mol}$ of MDA per $g$ of wet tissue.

The total antioxidant capacity (TAC) of lenses was measured on sample supernatant by 2,2 -azinobis (3-ethylbenzothiazoline-6-sulfonate) (ABTS) radical cation decolourization assay, according to the method of Re et al. (1999). The $\mathrm{ABTS}^{+}$radical was generated by chemical reaction with potassium persulfate. For this propose, $25 \mathrm{ml}$ of ABTS $(7 \mathrm{mM})$ was spiked with $440 \mu 1$ of potassium persulfate $(140 \mathrm{mM})$ and allowed to stand in darkness at room temperature for $12-16 \mathrm{~h}$ (time required for the formation of the radical). Trolox was used as standard and the total antioxidant capacity of samples was defined as the concentration of Trolox having equivalent activity as $\mu \mathrm{mol} / \mathrm{g}$ eye wet weight.

Alpha-tocopherol in lenses sample was determined using a procedure of Zhao et al. (2004) modified. Samples were analysed by an HPLC system (Kontron Instruments, Milan, Italy) consisting of an autosampler (HPLC autosampler 360, Kontron Instruments, Milan, Italy) with a loop of $20 \mu$, a high-pressure pump and a C18 column $5 \mu \mathrm{m}, 250 \times 4.60 \mathrm{~mm}$ (Phenomenex, Torrance, CA, USA). The mobile phase consisted of acetonitrile and methanol $(75: 25 \mathrm{v} / \mathrm{v})$, and a flow rate of $1 \mathrm{ml} / \mathrm{min}$ was used. Alpha-tocopherol was identified using a fluorimeter detector and comparing the samples retention time with the pure standards $(97 \%)$ purchased from Sigma-Aldrich (St. Louis, MO, USA). The quantification was carried out using the Geminyx system (version 1.91) comparing the area sample peak with that of the reference standards curve. Results were expressed as $\mu \mathrm{mol} / \mathrm{mg}$ of eye-wet weight. 


\section{Statistical analysis}

One-way analysis of variance (ANOVA) was used to determine the effect of groups and Scheffe's test was performed to estimate significant differences among them. Indeed as indicated, comparisons were performed among the CG, IG, G30 and G60 groups. Statistical tests were performed with SPSS 19 for Windows.

\section{Results}

\section{Antioxidant markers in rabbit aqueous humor}

In Table 1 are summarized the effect of UVR on aqueous humor of exposed animals. A significant increase of GSSG and $\mathrm{H}_{2} \mathrm{O}_{2}$ was recorded in UV-induced rabbits (IG) when compared to controls (GSSG: $2.733 \pm 0.009 \mu \mathrm{mol} / \mathrm{ml}$ and $0.650 \pm 0.006 \mu \mathrm{mol} / \mathrm{ml}$, $\mathrm{p}<0.001 ; \quad \mathrm{H}_{2} \mathrm{O}_{2}: \quad 0.251 \pm 0.002 \mathrm{mmol} / \mathrm{ml} \quad$ and $0.053 \pm 0.001 \mathrm{mmol} / \mathrm{ml}, \mathrm{p}<0.001$, respectively $\mathrm{IG}$ vs. controls). Contrarily, ascorbic acid levels were significantly lower in IG group than in control eyes $(0.277 \pm 0.001 \mathrm{mmol} / \mathrm{ml}$ and $1.080 \pm 0.002 \mathrm{mmol} / \mathrm{ml}$, $\mathrm{p}<0.001$, respectively).

In the groups exposed to UVR rays for 30 and $60 \mathrm{~min}$, and treated with the topical anti-oxidant formulation every $15 \mathrm{~min}$ for three hours, the following findings were recorded. In the G30 group the GSSG, $\mathrm{H}_{2} \mathrm{O}_{2}$ and ascorbic acid levels were similar to those recorded in controls (GSSG: $0.683 \pm 0.003 \mu \mathrm{mol} / \mathrm{ml}$ vs. $0.650 \pm 0.006 \mu \mathrm{mol} / \mathrm{ml} ; \quad \mathrm{H}_{2} \mathrm{O}_{2}: \quad 0.059 \pm 0.002 \mu \mathrm{mol} / \mathrm{ml}$; ascorbic acid: $0.893 \pm 0.006 \mathrm{mmol} / \mathrm{ml}, \mathrm{p}=$ not significant). Whereas in the G60 group the three markers significantly differ from control group, although at a lower degree of significance (GSSG: $\quad 0.737 \pm 0.008 \mu \mathrm{mol} / \mathrm{ml} ; \quad \mathrm{H}_{2} \mathrm{O}_{2}$ : $0.088 \pm 0.003 \mu \mathrm{mol} / \mathrm{ml}$; ascorbic acid $0.667 \pm 0.007$ $\mathrm{mmol} / \mathrm{ml}, \mathrm{p}<0.05)$.

The difference among the three treated groups was also significant. In fact the amount of GSSG and $\mathrm{H}_{2} \mathrm{O}_{2}$ recorded in the $\mathrm{G} 30$ group was significantly lower than that found in the IG group $(\mathrm{p}<0.001)$, whereas the ascorbic acid content was lowest $(0.893 \pm 0.006 \mathrm{mmol} / \mathrm{ml}$ vs. $0.227 \pm 0.001 \mathrm{mmol} / \mathrm{ml}, \mathrm{p}<0.001)$. The levels of GSSG and $\mathrm{H}_{2} \mathrm{O}_{2}$ in the $\mathrm{G} 60$ group were significantly lower than in IG group $(p<0.05)$. Lastly, the difference between $\mathrm{G} 30$ and G60 groups demonstrated that the protective effect exerted by the topical antioxidant formulation was significantly more effective at the lowest degree of exposure ( $\mathrm{p}<0.05$, G60 vs. G30).

Table 1. Aqueous humor oxidative status markers in rabbit. Results are expressed as mean values $\pm \mathrm{SE}$.

\begin{tabular}{|c|c|c|c|c|}
\hline \multirow[b]{2}{*}{ Parameters } & \multicolumn{4}{|c|}{ Group $^{\dagger}$} \\
\hline & $\mathbf{C G}$ & IG & G30 & G60 \\
\hline GSSG, $\mu \mathrm{mol} / \mathrm{ml}$ & $0.650 \pm 0.006$ & $2.733 \pm 0.009 * *$ & $0.683 \pm 0.003^{\circ}$ & $0.737 \pm 0.008^{*} \AA^{\#}$ \\
\hline Ascorbic acid, $\mathrm{mmol} / \mathrm{ml}$ & $1.080 \pm 0.002$ & $0.227 \pm 0.001 * *$ & $0.893 \pm 0.006^{\circ}$ & $0.667 \pm 0.007 *{ }^{\sharp} \#$ \\
\hline $\mathrm{H}_{2} \mathrm{O}_{2}, \mathrm{mmol} / \mathrm{ml}$ & $0.053 \pm 0.001$ & $0.251 \pm 0.002 * *$ & $0.059 \pm 0.002^{\circ}$ & $0.088 \pm 0.003 * 3^{\#}$ \\
\hline
\end{tabular}

GSSG=oxidized glutathione; $\mathrm{H}_{2} \mathrm{O}_{2}$ hydrogen peroxide; ${ }^{+} \mathrm{CG}=$ control group; ${ }^{+} \mathrm{IG}=$ irradiation group without eye drop; ${ }^{\dagger} \mathrm{G} 30=$ irradiation for 30 min with eye drops every 15 min for three hours; ${ }^{+} \mathrm{G} 60=$ irradiation for 60 min with eye drops every 15 min for three hours. ${ }^{*} p<0.05 ; * * p<0.001$ (treated groups vs. control group); ${ }^{\circ} \mathrm{p}<0.001$ (G30 vs. IG); ${ }^{\S} \mathrm{p}<0.05$ (G60 vs. IG); ${ }^{\#} \mathrm{p}<0.05$ (G60 vs. G30).

\section{Antioxidant markers in rabbit lens}

In Table 2 are summarized the effect of UV on lens of exposed animals. A significant decrease of alpha tocopherol and TAC was recorded in IG group animals as compared to controls (alpha tocopherol: 0.012 \pm 0.001 $\mu \mathrm{mol} / \mathrm{ml}$; TAC $90.101 \pm 0.163 \mu \mathrm{mol} \quad \mathrm{TE} / \mathrm{g}, \quad \mathrm{p}<0.001$, respectively IG vs. control). Contrarily, MDA levels were significantly higher in UV-induced rabbits than in control eyes $(1.837 \pm 0.023 \mu \mathrm{mol} / \mathrm{g}$ and $1.527 \pm 0.002 \mu \mathrm{mol} / \mathrm{g}$, $\mathrm{p}<0.001)$.

In the groups exposed to UV rays for 30 and $60 \mathrm{~min}$, and treated with the topical anti-oxidant formulation every $15 \mathrm{~min}$ for three hours, the following findings were recorded. In the G30 group the alpha tocopherol, MDA and TAC levels do not significantly differ from those recorded in controls (alpha tocopherol: $0.110 \pm 0.005 \mu \mathrm{mol} / \mathrm{mg}$; MDA: $1.517 \pm 0.018 \mu \mathrm{mol} / \mathrm{g}$; TAC: $138.830 \pm 0.546 \mu \mathrm{mol} \mathrm{TE} / \mathrm{g}, \mathrm{p}=$ not significant). Whereas in the G60 group the three markers significantly differ from control group, although at a lower degree of significance (alpha tocopherol: $0.078 \pm 0.002 \mu \mathrm{mol} / \mathrm{mg} ; \quad \mathrm{MDA}$ : $1.643 \pm 0.012 \mu \mathrm{mol} / \mathrm{g} ; \quad$ TAC: $\quad 122.503 \pm 0.346 \mathrm{mmol} / \mathrm{ml}$, $\mathrm{p}<0.05)$.

The difference among the three treated groups 
was also significant. In fact the amount of alpha tocopherol and TAC recorded in the G30 group was significantly higher than that found in the IG group $(\mathrm{p}<0.001)$, whereas the MDA content was lowest $(1.517 \pm 0.018 \mu \mathrm{mol} / \mathrm{g}$ vs. $1.837 \pm 0.023 \mu \mathrm{mol} / \mathrm{g}, \mathrm{p}<0.001)$. The levels of Alpha tocopherol and TAC in the G60 group were significantly lower than in IG group $(\mathrm{p}<0.05)$, whereas the MDA concentration was highest $(\mathrm{p}<0.05)$. Lastly, the difference between G30 and G60 groups demonstrated that the protective effect exerted by the topical antioxidant formulation was significantly more effective at the lowest degree of exposure ( $\mathrm{p}<0.05$, G60 vs. G30).

Table 2. Lenses oxidative status markers in rabbit. Results are expressed as mean values \pm SE.

\begin{tabular}{|c|c|c|c|c|}
\hline \multirow[b]{2}{*}{ Parameters } & \multicolumn{4}{|c|}{ Group $^{\dagger}$} \\
\hline & CG & IG & G30 & G60 \\
\hline Alpha-tocopherol, $\mu \mathrm{mol} / \mathrm{mg}$ & $0.120 \pm 0.001$ & $0.012 \pm 0.001 * *$ & $0.110 \pm 0.005^{\circ}$ & $0.078 \pm 0.002 *{ }^{\S \#}$ \\
\hline$M D A, \mu \mathrm{mol} / \mathrm{g}$ & $1.527 \pm 0.002$ & $1.837 \pm 0.023 * *$ & $1.517 \pm 0.018^{\circ}$ & $1.643 \pm 0.012 * 8^{\#}$ \\
\hline$T A C, \mu m o l ~ T E / g$ & $140.170 \pm 0.176$ & $90.101 \pm 0.163 * *$ & $138.830 \pm 0.546^{\circ}$ & $122.503 \pm 0.346^{* \S^{\#}}$ \\
\hline
\end{tabular}

$\mathrm{MDA}=$ malondialdehyde; $\mathrm{TAC}=$ total antioxidant activity; ${ }^{\dagger} \mathrm{CG}=$ control group; ${ }^{\dagger} \mathrm{IG}=$ irradiation group without eye drop; ${ }^{\dagger} \mathrm{G} 30=$ irradiation for $30 \mathrm{~min}$ with eye drops every $15 \mathrm{~min}$ for three hours; ${ }^{\dagger} \mathrm{G} 60=$ irradiation for 60 min with eye drop every 15 min for three hours. ${ }^{*} p<0.05 ; * * p<0.001$ (treated groups vs. control group); ${ }^{\circ} p<0.001$ (G30 vs. IG); ${ }^{\S} p<0.05$ (G60 vs. IG); ${ }^{\#} p<0.05$ (G60 vs. G30).

\section{Discussion}

The results of this study demonstrate that topical application of a solution containing riboflavin, d- $\alpha$-tocopheryl polyethylene glycol, proline, glycine, lysine and leucine significantly counteracts the UV-induced oxidative stress in both aqueous humor and lens of exposed rabbit. UVR stimulates the production of unstable and highly reactive oxygen species (ROS). UVR light trigger ROS generation (Riley et al. 1986). In aqueous humor, ROS are neutralized in two ways: firstly, through the dilution of the toxic compounds by the continuous aqueous humor production; secondly, by coupling reactive species both enzymatically (SOD, CAT and GSH-Px) and non-enzymatically (GSH and ascorbic acid) (Costagliola et al. 1996). Ascorbate represents the first line of defense against free radical species; the levels of $\mathrm{H}_{2} \mathrm{O}_{2}$ in aqueous humor indicate the ability of ascorbate to react with ROS (Giblin et al. 1984). In our series, the levels of $\mathrm{H}_{2} \mathrm{O}_{2}$ and GSSG arise about five times as compared to controls; the decrease of ascorbic acid was of the same order of magnitude. In the groups receiving the protective topical treatment, at the lowest exposure $(30 \mathrm{~min})$ the damage were completely counterbalanced; whereas in the group exposed for $60 \mathrm{~min}$ the deleterious effects were significantly minimized (Table 1).

Despite the presence of these active systems, at the greater UVR exposure, the aqueous humor scavenger effect declines, and the involvement of lens can easily occur. Furthermore, aqueous humor has about $78 \%$ transmittance of wavelengths in the $300-320 \mathrm{~nm}$ range (Hightower and McCready 1992), allowing them an easily achievement of the anterior surface of the lens. Mammalian lens contains several classes of chromophores that are absorbers of energy: the tryptophan derived UV filters that enable the lens to act just as a UV filter to protect the retina (Lim et al. 2017). These compounds, acting as photosensitizers, once excited by UV-in presence of oxygen can generate free radicals. The high levels of ATP in the lens even contribute to absorb UV light (Pintor 2011). Being the lens particularly susceptible to oxidative damage, a valuable antioxidant defense system provides to maintain its transparency. The lines of defense are both enzymatic (SOD, CAT and GSH-Px peroxidase) and non-enzymatic (ascorbic acid and GSH) (Costagliola et al. 1996). Despite the presence of these defensive mechanisms, lens exposure to UV results in peroxidative damage to membrane lipids, with a consequent increase in MDA levels. Although lipid peroxidation is the most obvious detrimental phenomenon related to UV exposure, other consequences also occur in lens in the presence of free radical species: enzyme inactivation, protein crosslinking and aggregation, lens fluorescence, and DNA alteration. All these phenomena may be responsible for the development of further lens opacities (Costagliola et al. 1997). In our series, at the MDA increase 
corresponded a parallel decrease of both alpha tocopherol and total antioxidant activity (TAC). Alpha-tocopherol protects against UV-induced damage in in vitro (Zigman et al. 1995), and in in vivo animal experiments (Reddy and Bhat 1999). Lastly, the TAC reduction after irradiation further confirms that UV-induced cataractogenesis is secondary to oxidative damage on lens enzymes and that antioxidants play a protective role against this damage. In fact, in the groups receiving the protective topical treatment, at the lowest exposure (30 $\mathrm{min}$ ) the damage did not take place, whereas in the group exposed for $60 \mathrm{~min}$ the negative effects occurred at a lowest intensity (Table 2).

In conclusion, our findings demonstrate that UVR exposure causes a decrease in antioxidant activity due to a parallel increase in free radical production. The irradiance on the cornea was about 60 times the maximum exposure of the human cornea to UVA contained in sunlight (Zigman 1995), a condition quite different from the real life. The choice of rabbits as animal model is based on the statement that it represents the model widely used in ophthalmic research (Gwon 2009). UV light increases the risks of several eye diseases; some of these-like photokeratitis and solar retinopathy- are related to acute UVR exposure, whereas, pterygium, cataract, age related macular degeneration and skin cancer in the periorbital region take many years to develop. The relevance of chronic UVR exposure is much higher than the acute one, and epidemiologic and animal studies demonstrate that the risks to acquire serious eye disorders is directly correlated with the cumulative UVR exposure (Behar-Cohen et al. 2014).

Since eye function depends on direct exposure to light, the possibility to protect eye tissues from UVR is very limited, and to date mainly consists in wearing hats and UV-blocking sunglasses (Turbert 2014). The application of protective eye drops makes the cornea, the first structure that UVR encounter throughout the optic axis, an effective defender against UV exposure, as well as the burn of corneal epithelium induced by alkali (Ambrosone et al. 2014), enhancing the activity of the antioxidant defense system and inhibiting lipid peroxidation. In fact, in irradiated eyes, the treatment avoids the dramatic loss of ascorbic acid in aqueous humor and of alpha tocopherol and TAC in lens and counteracts the $\mathrm{H}_{2} \mathrm{O}_{2}$ and GSSG increase in aqueous humor, as well as of the MDA levels in the lens. Although evidence has been accumulating that the eye is vulnerable to UV damage, a comprehensive generally accepted definition of a sun protection factor for the eye (similar to a skin-sun protection factor) is lacking. The findings of the present study demonstrate that the tested eye-drop antioxidant formulation represent an answer to this problem, due to its effectiveness in preventing UV radiation-induced oxidative stress in in vivo animal model.

\section{Conflict of Interest}

The authors declare that they do not have conflict of interests (political, personal, religious, ideological, academic, intellectual, commercial, or otherwise) regarding the publication of the paper.

\section{Acknowledgements}

The investigation was conducted with the collaboration and contribution of all co-authors. Authors would like to thank Servimed Industrial s.p.a. (Rome, Italy) in funding the present work.

\section{References}

ALY EM, ALI MA: Malays effects of bilberry on deoxyribonucleic acid damage and oxidant-antioxidant balance in the lens, induced by ultraviolet radiation. J Med Sci 21: 11-18, 2014.

AMBROSONE L, GUERRA G, CINELLI M, FILIPPELLI M, MOSCA M, VIZZARRI F, GIORGIO D, COSTAGLIOLA C: Corneal epithelial wound healing promoted by verbascoside-based liposomal eyedrops. Biomed Res Int 2014: 471642, 2014.

BEHAR-COHEN F, BAILLET G, DE AYGUAVIVES T, GARCIA PO, KRUTMANN J, PEÑA-GARCÍA P, REME C, WOLFFSOHN JS: Ultraviolet damage to the eye revisited: eye-sun protection factor (E-SPF®), a new ultraviolet protection label for eyewear. Clin Ophthalmol 8: 87-104, 2014.

BEISSERT S, LOSER K: Molecular and cellular mechanisms of photocarcinogenesis. Photochem Photobiol 84: 29-34, 2008.

BERGMEYER HU: Methods of Enzymatic Analysis XXIV. Academic Press, New York and London, 1963, 1088 p. 
CARUBELLI R, NORDQUIST RE, ROWSEY JJ: Role of reactive oxygen species in corneal ulceration. Effect of hydrogen peroxide generated in situ. Cornea 9: 161-169, 1990.

COSTAGLIOLA C, BALESTRIERI P, FIORETTI F, FRUNZIO S, RINALDI M, SCIBELLI G, SEBASTIANI A, RINALDI E: ArF $193 \mathrm{~nm}$ excimer laser corneal surgery as a possible risk factor in cataractogenesis. Exp Eye Res 58: 453-457, 1994.

COSTAGLIOLA C, Di GIOVANNI A, RINALDI M, SCIBELLI G, FIORETTI F: Photorefractive keratectomy and cataract. Surv Ophthalmol 42 (Suppl 1): S133-S140, 1997.

ČEJKOVÁ J, TÍPEK S, CRKOVSKÁ J, ARDAN T, PLÁTENÍK J, ČEJKA Č, MIDELFART A: UV rays, the prooxidant/antioxidant imbalance in the cornea and oxidative eye damage. Physiol Res 53: 1-10, 2004.

ČEJKOVÁ J, TÍPEK S, CRKOVSKÁ J, ARDAN T: Changes of antioxidant enzymes in the cornea of albino rabbits irradiated with UVB rays. Histochemical and biochemical study. Histol Histopathol 15: 1043-1050, 2000.

DAUSH D, KLEIN RJ, SCHRODER E: In: Ophthalmic Excimer Laser Surgery-Clinical Results. Editions du Signe. Strasbourg, 1991, pp 89-126.

EDIGER MN: Excimer laser induced fluorescence of rabbit cornea: radiometric measurement through the cornea. Lasers Surg Med 11: 93-98, 1991.

GIBLIN FJ, LIN LR, SIMPANYA MF, LEVERENZ VR, FICK CE: A Class I UV-blocking (senofilcon A) soft contact lens prevents UVA-induced yellow fluorescence and NADH loss in the rabbit lens nucleus in vivo. Exp Eye Res 102: 17-27, 2012.

GIBLIN FJ, MCCREADY JP, KODAMA T, REDDY VN: A direct correlation between the levels of ascorbic acid and H2O2 in aqueous humour. Exp Eye Res 38: 87-93, 1984.

GLICKMAN RD: Ultraviolet phototoxicity to the retina. Eye Contact Lens 37: 196-205, 2011.

GWON A: The rabbit in cataract/IOL surgery. In: Animal Models in Eye Research. TSONIS PA (ed.), Academic Press, 2008, pp 184-204.

HIGHTOWER K, MCCREADY J: Physiological effects of UVB irradiation on cultured rabbit lens. Invest Ophthalmol Vis Sci 33: 1783-1787, 1992.

JOHAR SR, RAWAL UM, JAIN NK, VASAVADA AR: Sequential effects of ultraviolet radiation on the histomorphology, cell density and antioxidative status of the lens epithelium - an in vivo study. Photochem Photobiol 78: 306-311, 2003.

KOCHEVAR IE: Cytoxicity and mutagenicity of excimer laser radiation. Lasers Surg Med 9: 440-445, 1989.

LIM JC, UMAPATHY A, GREY AC, VAGHEFI E, DONALDSON PJ: Novel roles for the lens in preserving overall ocular health. Exp Eye Res 156: 117-123, 2017.

MCCARTY C, TAYLOR HR: Light and risk for age-related eye diseases. In: Nutritional and Environmental Influences on the Eye. TAYLOR A (ed.), CRC Press, New York, 1999, pp 135-150.

MCCARTY CA, TAYLOR HR: A review of the epidemiologic evidence linking ultraviolet radiation and cataracts. Dev Ophthalmol 35: 21-31, 2002.

MIDELFART A: Ultraviolet radiation and cataract. Acta Ophthalmol Scand 83: 642-644, 2003.

OHKAWA H, OHISHI N, YAGI K: Assay for lipid peroxides in animal tissues by thiobarbituric acid reaction. Anal Biochem 95: 351-358, 1979.

PINTOR J: Why are such high concentrations of nucleotides in the lens? Purinerg Signal 7: 169-170, 2011.

PIRIE A: Glutathione peroxidase in lens and a source of hydrogen peroxide in aqueous humor. Biochem J 96: 244-253, 1965.

RE R, PELlEGRINI N, PROTEGGENTE A, PANNAlA A, YANG M RICE-EVANS C: Antioxidant activity applying an improved ABTS radical cation decolorization assay. Free Radic Biol Med 26: 1231-1237, 1999.

REDDY GB, BHAT KS: Protection against UVB inactivation (in vitro) of rat lens enzymes by natural antioxidants. Mol Cell Biochem 194: 41-45, 1999.

RILEY MV, SCHWARTZ CA, PETERS MI: Interaction of ascorbate and H202: implications for in vitro studies of lens and cornea. Curr Eye Res 5: 207-216, 1986.

ROBERTS JE: Ultraviolet radiation as a risk factor for cataract and macular degeneration. Eye Contact Lens 37 : 246-249, 2011. 
SAID T, DUTOT M, MARTIN C, BEAUDEUX JL, BOUCHERD C, ENEE E, BAUDOUIN C, WARNET JM, RAT P: Cytoprotective effect against UV-induced DNA damage and oxidative stress: Role of new biological UV filter. Eur J Pharm Sci 30: 203-210, 2007.

STRAUB FB: Reinigung der Apfelsäuredehydrase und die Bedeutung der Zellstruktur in der Apfelsäuredehydrierung. (In German) Hoppe-Seyler Z Physiol Chem 275: 63-72, 1942.

SUI GY, LIU GC, LIU GY, GAO YY, DENG Y, WANG WY, TONQ SH, WANG L: Is sunlight exposure a risk factor for age-related macular degeneration? A systematic review and meta-analysis. Br J Ophthalmol 97: 389-394, 2013.

TURBERT D: The sun, UV radiation and your eyes. Tips \& Prevention. Amer Acad Ophthalmol Aug. $28,2014$.

WU ZH, WANG MR, YAN QC, PU W, ZHANG JS: UV-induced DNA damage and protective effects of antioxidants on DNA damage in human lens epithelial cells studied with comet assay. (In Chinese) Zhonghua Yan Ke Za Zhi 42: 1002-1007, 2006.

ZHAO B, THAM SY, LU J, LAI MH, LEE LK, MOOCHHALA SM: Simultaneous determination of vitamins C, E and $\beta$ carotene in human plasma by high-performance liquid chromatography with photodiode-array detection. J Pharm Pharmac Sci 7: 200-204, 2004.

ZIGMAN S, MCDANIEL T, SCHULTZ JB, REDDAN J, MEYDANI M: Damage to cultured lens epithelial cells of squirrels and rabbits by UV-A $(99.9 \%)$ plus UV-B (0.1\%) radiation and alpha tocopherol protection. $\mathrm{Mol}$ Cell Biochem 143: 35-46, 1995.

ZIGMAN S: Environmental near-UV radiation and cataracts. Optom Vis Sci 72: 899-901, 1995. 